\title{
Research Progress and Prospect of Well Integrity Technology
}

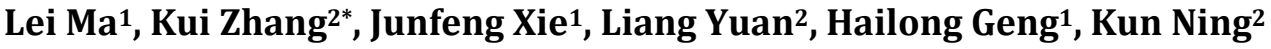 \\ ${ }^{1}$ Oil and Gas Engineering Institute, Petro China Tarim Oilfield Company, Korla, China \\ ${ }^{2}$ CNPC Engineering Technology R \& D Company Limited, Beijing, China \\ Email: *zhangkuidri@cnpc.com.cn
}

How to cite this paper: Ma, L., Zhang, K., Xie, J.F., Yuan, L., Geng, H.L. and Ning, K. (2020) Research Progress and Prospect of Well Integrity Technology. Journal of Power and Energy Engineering, 8, 45-54. https://doi.org/10.4236/jpee.2020.87004

Received: April 27, 2020

Accepted: July 29, 2020

Published: July 31, 2020

Copyright $\odot 2020$ by author(s) and Scientific Research Publishing Inc. This work is licensed under the Creative Commons Attribution International License (CC BY 4.0).

http://creativecommons.org/licenses/by/4.0/ (c) (i) Open Access

\begin{abstract}
Well integrity technology can effectively ensure the safety of the entire life cycle of oil and gas wells. With the exploration and development of more and more high-temperature, high-pressure, high-yield and deep wells, and the constantly increasing requirements for safety and environmental protection in various countries, well integrity technology has become a research hot spot in the oil industry. Based on the analysis of the four basic concepts of well integrity: full life cycle, well integrity management system, well barrier, and risk assessment, this article conducts a comparative analysis of the development history of well integrity technologies at home and abroad, and systematically summarizes foreign wells. The current status of integrity technology, based on the above investigation and analysis, puts forward suggestions for the next development direction of well integrity technology, which has certain guiding significance for the development of the integrity of the next step.
\end{abstract}

\section{Keywords}

Well Integrity, Basic Concept, Development Course, Technology Status, Prospect

\section{Introduction}

Well integrity refers to the comprehensive application of technical, operational and organizational management solutions to reduce the risk of uncontrolled leakage of formation fluids throughout the life of the well [1] [2]. Throughout the entire life cycle of the well, by ensuring that the safety risk level of oil and gas well construction and operation is controlled within a reasonable and acceptable range, the goals of reducing oil and gas well accidents and economically and safely operating the oil and gas well are achieved.

The consequences of well integrity issues can be equipment failures, casual- 
ties, loss of production and environmental pollution, and can lead to huge economic losses, severe damage to corporate reputation, and even company closures. In recent years, as more and more high-temperature wells, high-pressure wells, high-productivity wells and deep wells have been explored and developed, the challenges of well integrity have become increasingly severe. Once the integrity problem occurs, the consequences for oil companies will become increasingly serious. Especially after the Deepwater Horizon accident in the Gulf of Mexico in 2010, well integrity caused widespread concern worldwide.

\section{Development History of Well Integrity}

\subsection{Development History of Well Integrity Technology}

In 1977, the Bravo blowout of Phillips Petroleum Company, Norway first proposed the concept of well integrity. In the following nearly 40 years, well integrity technology has been developed and widely used in Norway, the United Kingdom, and the United States.

In 1996, the Norwegian Petroleum Safety Authority (PSA) began to systematically conduct well integrity technology research and promote its application in Norwegian offshore oil and gas fields.

In 2001, in response to the well integrity challenges caused by annulus pressure in the oil and gas wells in the Gulf of Mexico, Louisiana State University, Schlumberger, Stress Engineering Services, etc. carried out continuous research and published "Continuous Casing Pressure Diagnosis in Wells and final reports on remediation and remedial measures "[3]" Comments on the phenomenon of continuous casing pressure on the outer edge of the continental shelf "[4]" Best practices for the prevention and control of continuous casing pressure "[5] and other research reports, systematic analysis the annular pressure conditions of oil and gas wells in the outer continental shelf area of the United States were analyzed. Based on the statistical analysis of a large number of field data, researches on diagnostic analysis, preventive measures, and remedial measures of annular pressure were carried out.

In 2004, following the blowout accident at the Norwegian National Petroleum Corporation's Snorre A platform, the Norwegian Petroleum Standardization Organization NORSOK D-010 "Guidelines for Well Integrity during Drilling and Operations" released the third edition [6], which proposed the concept of well barrier management. The system describes the measures to ensure the integrity of the wellbore in the process of ensuring safe production. Various oil companies and operators have begun to pay attention to and use this standard.

In 2006, API first published the recommended practice RP 90 "Recommended Practice for Annular Pressure Management in Offshore Oilfields" designed to guide the management of annulus pressure in offshore oil and gas wells [7]; this recommendation covers the monitoring of annulus pressure and the diagnosis of annulus pressure testing, establishment of single well maximum annular working pressure (MAWOP), and recording of annular pressure. This recommended 
practice has become an important guidance method for managing annulus pressure in offshore oil and gas wells abroad.

In 2007, Norway released the Well Integrity Management Software (WIMS) for the first time and established the WIF Well Integrity Association. Many companies have developed their own well integrity management systems. A large number of oil companies have adopted well integrity management systems to improve well integrity technology and management level. Oil and gas well integrity management system is a continuous management, evaluation and verification system used to ensure the continuity and reliability of well design, construction, monitoring and maintenance throughout the life cycle.

In 2009, the American Petroleum Institute released the "API HF1 Wellbore Structure and Well Integrity Guidelines" for the protection of groundwater and the environment in response to the integrity of hydraulic fracturing wells [8].

In 2010, after BP's Macando blowout in the Gulf of Mexico, well integrity caused widespread concern and rapid development worldwide:

In 2011, the Norwegian Petroleum Industry Association developed the "OLF-117 Well Integrity Recommended Guide", which aims to guide well barrier design, well classification, and continuous annulus well killing management [9]. In the same year, the British Petroleum Association Published "OIL \& GAS UK-1 Suspended and Abandoned Well Plugging Material Requirements” [9] and “OIL \& GAS UK-2 Suspended and Abandoned Well Guidelines" [10], aiming to guide suspended and abandoned well operations design and construction;

In 2012, the British Petroleum Association released the "Oil \& Gas UK Well Integrity Guide" [11], which aims to guide well barrier design, installation and testing at all stages of the well's life cycle;

In 2013, the ISO organization released "ISO/TS 16530-2 Production Well Integrity" [12], which aims to guide the monitoring, testing and management of production well integrity. In the same year, the Norwegian Petroleum Standardization Organization absorbed the industry's complaints about the accident. Based on the 450 recommendations, the fourth edition of NORSOK D-010 [1] was revised and published;

In 2015, the American Petroleum Institute (API) released the API 100-1 "Fracturing-Well Integrity and Fracture Control" [13]; 2016 Life Cycle Well Integrity Guide Third Edition [14], API releases RP90-2 onshore annulus pressure management [15], OLF releases Well Integrity Recommended Guide revision [16]; 2017 ISO release 16530-1 full life cycle well Integrity management [17].

In recent years, well integrity monitoring, evaluation, and technology have developed rapidly abroad.

While a large number of well integrity technology research and standard preparation work have been carried out, developed countries have successively formulated and improved a large number of well integrity related laws and regulations to ensure the effective implementation of well integrity work. Norway's petroleum industry management regulations, petroleum equipment design and 
configuration regulations all require well barrier design and monitoring requirements; UK offshore installation safety case regulations, well design and construction regulations, and other requirements related to well integrity; EU offshore safety regulations recently issued requirements for independent well integrity reviews.

\subsection{Development History of Well Integrity Technology in China}

In response to the well integrity challenges faced by domestic oil and gas wells, especially high-temperature and high-pressure wells, based on the introduction of foreign advanced technology and management experience, CNPC, Sinopec and CNOOC have carried out well integrity technology research based on their own needs and achieved a certain application effect.

In 2005, Petro China Tarim Oilfield Company introduced the new concept of foreign well integrity to carry out the risk assessment of problem wells for the anomalous annulus pressure of multiple wells in the Kela 2 gas field. The API RP90 standard was used to calculate the maximum allowable pressure in each annulus and develop governance measures.

In 2008, Petro China Southwest Oil \& Gas Field Company relied on Longgang gas field to carry out related research on well integrity evaluation and formed a set of three high gas well integrity evaluation techniques.

From 2009 to 2011, CNPC Tarim Oilfield Branch conducted a large-scale survey of the integrity of the entire oilfield based on extensive international surveys of well integrity in response to multiple wells in the Dina 2 gas field. According to the concept of well integrity, measures for problem wells were formulated to ensure the safe and efficient development of the Dina 2 gas field.

Beginning in 2012, Petro China Tarim Oilfield Branch Co., Ltd. conducted research on well integrity technology systems to meet the new challenges of well integrity after large-scale production in the Dabei and Keshen blocks. Design and production well integrity control and other innovative technologies featuring three super gas well integrity technologies.

In 2014, Petro China Southwest Oil \& Gas Field Company complied with the enterprise standard of "Technical Specifications for Integrity Evaluation of High Temperature, High Pressure, and High Acid Gas Wells".

In 2015, led by Petro China Exploration and Production Branch, Tarim Oilfield Company and Southwest Oil \& Gas Field Company drafted the "Integrity Guidelines for High Temperature, High Pressure, and High Content Sulfur Wells" [18], becoming the first well integrity guidance in China. Document, and promote its application in all oil and gas fields of Petro China. In 2017, the "Design Guidelines for Integrity of High Temperature, High Pressure, and High Content Sulfur Wells" [19] and the "Integrity Management Guidelines for Integrity of High Temperature, High Pressure, and High Content Sulfur Wells" [20] were successively released, and finally a set of well integrity procedures were formed complete standard series of documents, design guidelines and manage- 
ment practices.

In response to the well integrity challenges faced by the ultra-deep, ultra-high pressure, and high-temperature gas wells in the Yuanba gas field, Sinopec continued to carry out work on annular pressure management and risk assessment, which provided effective technical support for the exploration and development of the Yuanba gas field.

In response to the integrity challenges of high-temperature and high-pressure gas wells in the South China Sea, CNOOC Limited carried out systematic research on well integrity technologies from the introduction of well barrier design concepts, and established well integrity organizations to ensure well integrity management.

Petro China, Sinopec, and CNOOC have all conducted research on well integrity with the characteristics of their own oil and gas fields, and have achieved certain results, and have completed some well integrity related standards and specifications. However, the domestic well complete technology is still relatively scattered, and there is still a certain gap compared with Norway, the United Kingdom and other advanced countries with well integrity technology.

\section{Status of Foreign Well Integrity Technology}

Since the concept of well integrity was introduced by Norway in 1977, Norway and the United Kingdom have carried out well integrity technology research for more than 40 years. The overall technology and management level have led the industry. At present, the technical status of advanced countries in the field of well integrity technology can be summarized as the following points:

1) Well integrity remains a worldwide problem

In the 2009 "SPE Forum-Beihai Well Integrity Challenge", nearly 100 participants gave the number of wells that had experienced anomalies at least once. An average of 1600 wells in 4700 production wells had at least one anomaly. From the statistics of oil and gas wells in the Gulf of Mexico, the British North Sea, and the Norwegian North Sea, the proportion of oil and gas wells with integrity problems is $45 \%, 34 \%$, and $18 \%$, respectively.

From the above statistics, we can see that at present, the problem of well integrity is still a worldwide problem. With the exploration and development of more and more ultra-deep high-pressure and high-temperature wells, well integrity will be a long-term challenge for the petroleum industry.

2) Formed more systematic well integrity regulations, standards and codes

In recent years, well integrity related laws, standards and specifications have developed rapidly, and some international industry associations and standardization organizations have issued standards, guidelines and recommended practices related to well integrity. Norway, the United Kingdom, the United States and other countries have successively issued a large number of supplementary standards related to well integrity, including the integrity design, construction, 
and maintenance of well barrier components such as pipe strings, downhole tools, and wellhead devices. Standards, guidelines and best practices are being revised and developed. At the same time, countries are continuously improving regulations related to well integrity. ISO and other international standards organizations have also started to compile well integrity standards, and initially formed some internationally-used well integrity management and specifications, but there are still some differences in the integrity technical requirements and management models of countries.

3) There are generally specialized well integrity posts and departments

Well integrity technology runs through the entire process from drilling, completion, production to abandoned wells. Foreign oil companies generally set up specialized departments and positions to coordinate overall well management and coordinate the internal and external work of the company.

Statoil should adopt a zero tolerance attitude towards the integrity of high temperature and high-pressure wells. Led by the Norwegian Petroleum Safety Authority (PSA), the Norwegian Petroleum Industry Association (OLF) is responsible for setting standards. The company's well integrity is inspected and evaluated, and the assessment results are publicly released, and a full-time well integrity engineer is set up to participate in each stage of the well's full life cycle.

BP began exploration of oil and gas well integrity management as early as 1977. Before 1980, well completion engineers were responsible for oil and gas well integrity management. Since 2000, a dedicated oil well integrity engineer position has been established, with full responsibility for oil and gas well integrity management, and runs through all stages of the oil and gas well's entire life cycle.

Abu Dhabi National Petroleum Corporation (AMDA) regards reservoir management, safety and well integrity as the company's core competitiveness, and has established a dedicated well integrity department to evaluate and confirm risks at all stages of drilling, completion and production. At the same time, coordinate the development of well integrity related work throughout the life cycle.

4) Well integrity assessment and design has become routine in wells with complex conditions

Well integrity assessment has become an important part of well integrity technology and runs through feasibility studies, conceptual design, detailed engineering design, production and disposal. Through continuous well integrity assessment, identify and evaluate potential hazards and risks, so as to take optimized design, improve construction technology, strengthen monitoring, and develop targeted emergency plans. The common practice of international oil companies is to form a risk register through continuous risk assessment, and continuously track, monitor and evaluate the hazards of high and medium risks.

The assessment and control of the risks of all important links are the key links of a wellbore intact. Because each well has undergone different stages of comple- 
tion, workover, or production, a signed certificate document is required to confirm that the purpose is to ensure that each well has been carefully inspected and meets well integrity standards. These certificates can be used as management tools. For example, Abu Dhabi National Petroleum Corporation (AMDA) uses a signed certificate document as a well integrity management method to ensure that each well meets the requirements of well integrity related standards. Three types of well integrity certificates are issued for drilling, workover and production.

Most international oil companies have established internal well integrity design standards based on industry standards and best practices, combined with their own oilfield characteristics and environment. For example, Norwegian Petroleum has established a series of technical documents for design requirements, including casing design, tubing design and verification, cementing design, drilling fluid management, well testing procedures, wellhead and tree specifications. This series of technical documents serves as the technical support for the well integrity management of Statoil. The quality of well construction is the key to ensuring the integrity of the whole life cycle well, and standardized well integrity design can effectively guarantee the safety of wells with complex conditions. Norway, Canada and other countries require well integrity assessment and design of HPHT wells, $\mathrm{CO}_{2}$ high pressure injection wells and other complex wells.

\section{5) Universal application of well integrity management software system}

Well integrity management software is commonly used in well integrity management systems. The well integrity management software system is based on a powerful database. The database contains a large number of oil and gas well failure cases and well barrier reliability test, analysis, and application data. Provide a strong basis for well integrity analysis, risk assessment, and proposal of governance plans.

Well integrity management software records well integrity data monitored in real time on the well site, combined with well integrity database, quickly analyzes the basic data of oil and gas wells and production data, and evaluates the potential risks of the wells on this basis, so as to obtain well barrier component maintenance, testing and repair programs. The application of a well integrity management software system can efficiently manage oil and gas wells, can involve well integrity risk events as early as possible, reduce the risk of deterioration of well integrity conditions, and extend the life of oil and gas wells by reducing failures.

6) Third-party audits are generally used to ensure the effective implementation of well integrity technologies

Well integrity third-party audits are designed to ensure that well design, construction, testing, and monitoring and maintenance are in compliance with regulatory requirements, industry best practices, and operators' internal procedural documents. General well integrity Third-party audits run through the entire life cycle of a well, and the inclusion of a single well is not limited to the following:

a) Well design, including tubing casing design, mud and cementing design, 
wellbore trajectory and well disposal design, etc.

b) Well construction plan review, deviation handling review;

c) Handover review when the drilling department delivers to the production department;

d) Well barrier test monitoring during production process; workover plan, disposal plan.

The third party audit of well integrity is an important guarantee to continuously ensure the state of well barrier technology and well integrity. The third party audit of well integrity is also a common practice of the industry and global oil companies:

a) The European Union has issued a new law requiring independent review of wells;

b) In Norway, independent third parties are required to review the whole life cycle of wells;

c) In the Middle East, the oil industry promotes the implementation of a "well passport" system to ensure Technical compliance and well integrity;

d) In the United States, the Ocean Energy Management Regulations and Enforcement Agency (BOEMRE) requires that wells be verified by an independent third party.

Regarding the specific requirements and practices of third-party audits, there are still differences between countries. The differences between the UK and Norway in third-party audits are shown in Table 1.

\section{7) Well integrity monitoring technology develops rapidly}

The monitoring of well integrity is reflected in the continuous or regular monitoring of the well barrier status during different phases of the well's life cycle. For example, continuous monitoring of hydraulic parameters, composition, and performance of drilling fluid during drilling; continuous monitoring of the annulus temperature and pressure of the oil jacket during production; and periodic pressure and functional tests of safety valves are all for verification the integrity of the well barrier state. Foreign HPHT well integrity monitoring technology has developed rapidly. At present, well integrity detection technology basically covers all well barrier components such as wellheads, completion components, tubing, and casing. Schlumberger, Baker Hughes, EXPRO, Marathon and other companies have established well integrity monitoring technology departments, with dedicated wellhead leakage monitoring equipment, which can regularly check the casing head, wellhead valves and safety valves for leaks.

Table 1. Differences between the UK and Norway in third-party audits.

\begin{tabular}{|c|c|c|}
\hline Audit contents & England & Norway \\
\hline $\begin{array}{l}\text { Evaluation and audit of design } \\
\text { and wellbore conditions }\end{array}$ & $\begin{array}{l}\text { Government } \\
\text { requirements must do }\end{array}$ & $\begin{array}{l}\text { Government requirements } \\
\text { must do }\end{array}$ \\
\hline $\begin{array}{l}\text { Audit of integrity-related personnel } \\
\text { and management }\end{array}$ & $\begin{array}{l}\text { Government } \\
\text { requirements must do }\end{array}$ & $\begin{array}{l}\text { The company decides } \\
\text { whether to do it or not }\end{array}$ \\
\hline
\end{tabular}




\section{Well Integrity Technology Development Outlook}

In recent years, in view of the well integrity challenges brought by more and more complex working wells, a lot of work has been carried out from three aspects, including technology, operation and management, at home and abroad, and certain effects have been achieved. However, with the constant depletion of conventional oil and gas resources, the well conditions and working conditions of domestic oil and gas wells will continue to deteriorate in the future, and well integrity will face more challenges. The author believes that the following areas should be carried out:

1) Accelerate the establishment and improvement of the well integrity organization structure. By establishing and improving the mechanism for the implementation, supervision, supervision and evaluation of well integrity work, ensure the effective operation of the well integrity management system and the research results and practical experience of well integrity. Effective implementation of management to ensure well integrity;

2) To further improve well integrity standards, through continuous improvement of well integrity standards, and continuously supplement the supplementary standards of various links to ensure that the standards are suitable for the new needs of the site, and the latest technological progress through standard curing, the well design and construction related to the integrity of the well can be supported;

3) Research on related bottleneck technologies, urgently need to carry out in-depth research on such mechanical problems as completion string dynamic damage mechanism and annulus zone well seepage mechanism and other mechanistic issues research, and then propose countermeasures. At the same time, there is an urgent need to complete the supporting work of ultra-high temperature well cementing technology and ultra-deep well workover technology.

\section{Conclusions}

1) Based on the analysis of four basic concepts of well integrity: life cycle, well integrity management system, well barrier and risk assessment, a comparative analysis of the development process of well integrity technology at home and abroad is carried out, at the same time, the current situation of foreign well integrity technology is systematically summarized.

2) Some suggestions on the next development direction of well integrity technology are put forward, which has a certain guiding significance for the development of well integrity work in the next step.

\section{Conflicts of Interest}

The authors declare no conflicts of interest regarding the publication of this paper.

\section{References}

[1] Norwegian Oil Industry Association and Federation of Norwegian Manufacturing 
Industries (2013) NORSOK D-010 Rev. 4, Well Integrity in Drilling and Well Operations. Strandveien.

[2] OLF (2011) No. 117 Rev. 1, Recommended Guidelines for Well Integrity. Strandveien.

[3] Wojtanowicz, A.K., Nishikawa, S. and Rong, X. (2001) Diagnosis and Remediation of Sustained Casing Pressure in Wells. Louisiana State University, Baton Rouge.

[4] Sathuvalli, U.B. and Suryanarayana, P.V. (2001) Best Practices for Prevention and Management of Sustained Casing Pressure. Stress Engineering Services, Inc., Houston.

[5] Bourgoyne, A.T. (2001) A Review of Sustained Casing Pressure Occurring on the OCS. Louisiana State University, Baton Rouge.

[6] Norwegian Oil Industry Association and Federation of Norwegian Manufacturing Industries (2004) NORSOK D-010 Rev. 3, Well Integrity in Drilling and Well Operations. Strandveien.

[7] American Petroleum Institute (2006) API RP 90, Annular Casing Pressure Management for Offshore Wells. API, Washington DC.

[8] American Petroleum Institute (2009) API Guidance Document HF1. Hydraulic Fracturing Operations-Well Construction and Integrity Guidelines. API, Washington DC.

[9] Oil \& Gas UK, Guidelines for the Abandonment of Wells.

[10] Oil \& Gas UK, Guidelines on Qualification of Materials for the Abandonment of Wells.

[11] Oil \& Gas UK (2012) Oil \& Gas UK, Well Integrity Guidelines, Issue 1. London.

[12] International Organization for Standardization (2013) ISO 16530-2 Well Integrity Part 2: Well Integrity for the Operational Phase.

[13] ANSI/API (2015) Recommended Practice 100-1, Hydraulic Fracturing-Well Integrity and Fracture Containment.

[14] Oil \& Gas UK (2016) Oil \& Gas UK, Well Life Cycle Integrity Guidelines, Issue 3. London.

[15] American Petroleum Institute (2016) API RP 90-2, Annular Casing Pressure Management for Onshore Wells. API, Washington DC.

[16] OLF (2016) No. 117 Rev. 2, Recommended Guidelines for Well Integrity. Strandveien.

[17] IOS/DIS (2017) 16530-1, Petroleum and Natural Gas Industries-Well Integrity-Life Cycle Governance.

[18] Wu, Q. and Zheng, X.Q. (2017) Integrity Guidelines for High Temperature, High Pressure and High Sulfur Wells. Petroleum Industry Press, Beijing.

[19] Wu, Q. and Zheng, X.Q. (2017) Code for Integrity Management of High Temperature, High Pressure and High Sulfur Content Wells. Petroleum Industry Press, Beijing.

[20] $\mathrm{Wu}$, Q. and Zheng, X.Q., et al. (2017) Design Guidelines for Integrity of High Temperature, High Pressure and High Sulfur Wells. Petroleum Industry Press, Beijing. 